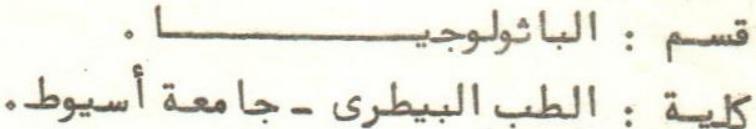

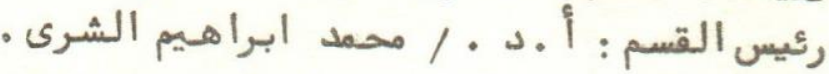

د راسات عن حد وث الالتهباب الشعبي الرهــوى

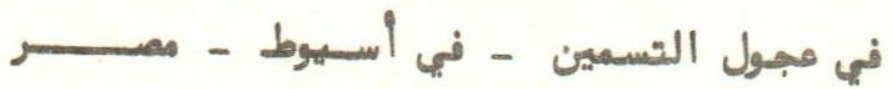

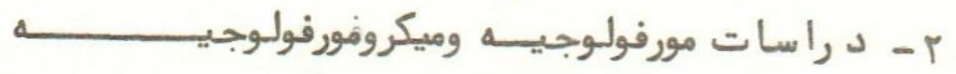

$$
\begin{aligned}
& \text { عبد اللطيف بيومي ، على السباعي ، صلاح د يسب، }
\end{aligned}
$$

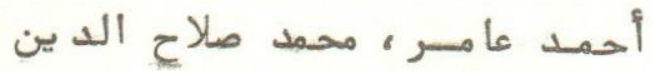

أجرى البحث في منطقة أسيوط على عد د سبعة عشر رأسا مسن

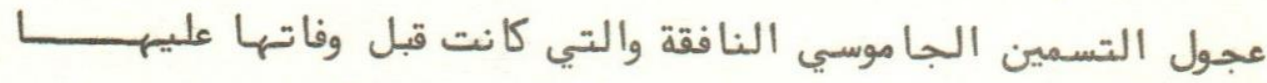

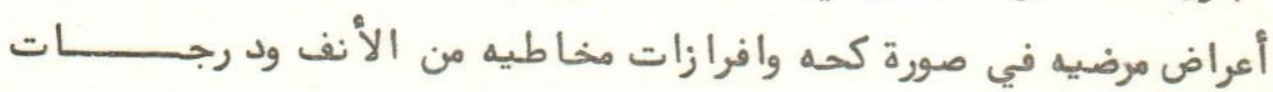

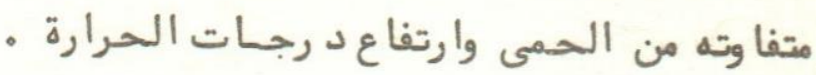

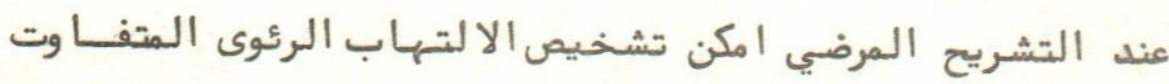

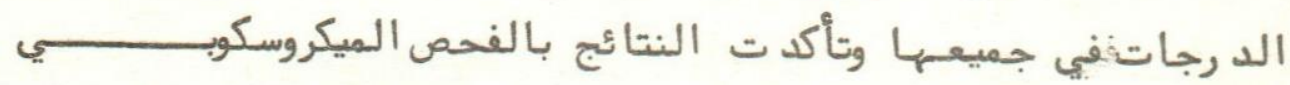

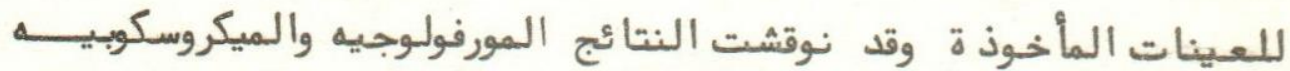

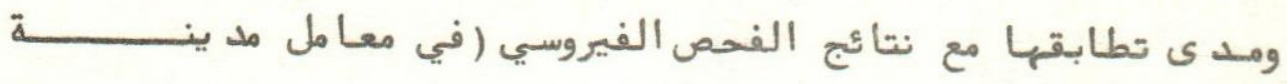

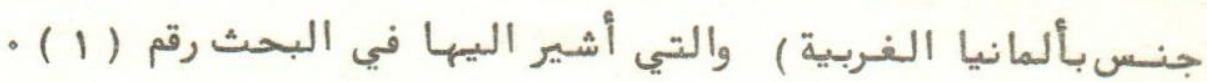


Depts. of Pathology and Animal Medicine, Faculty of Vet. Med., Assiut University,

Head of Depts. Prof. Dr. M.I. El-Sherry, \& Prof. Dr. I.H. Sokkar.

\title{
INVESTIGATION ON AN OUTBREAK OF ENZOOTIC BRONCHOPNEUMONIA IN FATTENING BUFFALO-CALVES IN ASSIUT, A.R.E. II. MORPHOLOGICAL AND MICROMORPHOLOGICAL STUDIES
}

(With 4 Figs.)

\author{
BY \\ A.H. BA YOUMI; A. EL-SEBAIE; S. DEEB; A.A. AMER \\ and M.S. YOUSSEF \\ (Received at 6/4/1983)
}

\begin{abstract}
SUMMARY
Postmortem and histopathological examinations were carried out on seventeen dead buffalo-calves obtained from an outbreak of respiratory distress in Assiut province. Morphological and micromorphological examinations revealed respiratory tract affection could be diagnosed as enzootic bronchopneumonia.
\end{abstract}

\section{INTRODUCTION}

Aetiologically, respiratory affection in cattle is a complex syndrome involving stress factors, bacterial and viral infections or combind effect (COLLIER et al. 1960; LEHMUKUHL and GOUGH, 1977; BREYSON et al. 1979; PIRIE, 1981 and AL-DARRAJI et al. $\overline{1982) .}$

Atypical pneumonia in fattening calves including giant cell type and cuffing type are described by (JARRETT 1956; BETTS et al. 1964; OMAR et al. 1966; LAMONT et al. 1968 and COLE 1971). In Egypt giant cell pneumonia was described by MOUSTAFA et al. (1975).

In the present study, an outbreak of enzootic bronchopneumonia in Assiut province was studied from the clinical, aetiological, haematological and morphological points of view. The clinical, aetiological and haematological methods and results were published by EL-SEBAIE et al. (1983).

\section{MATERIAL and METHODS}

Seventeen dead buffalo-calves with an average body weight of $150 \mathrm{~kg}$ and age of 9-12 months were collected from an outbreakof respiratory distress in Assiut province and were subjected to morphological and micromorphological studies.

Necropsy of those calves was performed as soon as possible after death. The different organs were carefully examined. For histological preparations, tissue specimens from the trachea, lung, liver, kidney, heart intestine, spleen and brain were fixed in 10\% neutral buffered formalin. Paraffin sections were prepared and stained with haematoxylin and eosin. Differential stains used included turnbull blue method, ferric ferricyanide method and Mallory trichrome stains.

Bacteriological, serological and haematological methods and results were published by EL-SEBAIE et al. (1983).

Assiut Vet.Med.J. Vol. 14, No. 27, 1985. 


\section{A.H. BAYOUML, et al.}

\section{RESULTS}

\section{Macroscopic findings:}

In all cases, the most significant lesions devloped in the respiratory tract. The mucosa of the entire nasal tract was congested, swollen and in few cases contained petochiae. Fibrinopurulent exudate, which was losely attached to the surface of the mucosa and partially occluding the meatuses, was also observed. Moreover, mucopurulent exudate was seen in the palatine and maxillary sinuses. The mucosa of the pharynx and larynx were hyperaemic, whereas mucopurulent discharge, occasionally tinged with blood, was seen in the trachea and bronchi. In the lung, areas of pneumonic consolidation asociated with areas of atelectasis and others of emphysema were observed. The consolidated areas were sharply demarcated from the healthy lung tissue and appeared granular, red to dark red or even greyish brown in colour. When the cut surface was squeezed, mucopurulent exudate escaped from the bronchi and bronchioles. In four cases, dense adhesive pleuritis accompanied with multiple subpleural focal suppurations in the cardiac and apical lobes were demonstrated. The abscesses were of different sizes, up to hazel nut sized abscesses, and were usually surrounded by pneumonic foci. The bronchial lymph nodes were usually enlarged, congested and oedematous.

Examination of other organs revealed that, the pericardium was oedematous, epaque and the pericardial sac was mostly distended with thin transudate; in five cases, fibrinous pericarditis was observed (Fig. 1). Petecheal and ecchymotic haemorrhages were present beneath the epicardium and also subendocardially. The heart muscles were flabby. The small intestine showed mild to severe catarrhal enteritis; its serosal vessels were congested. The liver was congested, sometimes was markedly enlarged, with rounded borders and appeared pale yellow. Only in three cases focal white necrotic foci could be observed in the right lobe of the liver. The kidneys were congested and slightly enlarged.

\section{Microscopic findings:}

Microscopical examination of the lung reyealed different pictures of inflammatory processes. The latter varied not only in severity but also in extent and nature from animal to animal and even from one area to another in the same animal. The principal microscopic feature consisted of exudative and proliforative reactions associated with necrotic areas. The latter were present side by side with the inflammed lung tissue. Suppuration and absecessation were seen in four cases.

The exudative reaction was manifested by serofibrinous cellular bronchopneumonia with atelectasis and emphysema. The main cellular inflammatory reaction in the alveoli consisted of infiltration of neutrophils and mononuclear cells. The exudative process involves also the interstitial tissue by whcih the interalveolar septa were thickened due to congested vessels, accumulations of serous or fibrinous exudate and cellular infiltrations. These were associated with areas of alveolar haemorrhages and muce-purulent bronchopneumonia. Vascular degenerative changes, perivascular oedema and areas of sequestrations were also observed.

The proliferative reaction consisted of peribronchial lymphocytic hyperplasia forming either seperate nodules or associated with histiocytic cellular proliferations. Cellular proliferation of the wall of the bronchi and bronchioles, (Fig. 2), mostly lead to narrowing or occlusion of their lumens. Many macrophages and giant cells were seen in the alveolar lumens (Fig. 3). The proliferative reaction was also observed in the interstitial tissue in the form of great thickening due to proliferative septal cells, large macrophages and fibroblastic proliferations (Fig. 4). The latter was also 


\section{BRONCHOPNEUMONIA IN CALVES}

observed around the suppurative and necrotic foci. The pleura in six cases showed chronic inflammatory processes. Perivascular round cell accumulations were also observed. Focal necrobiotic changes could be observed in the lymph nodes draining the respiratory tract.

Examination of the liver revealed degenerative and necrobiotic changes ranged from cloudy swelling to fatty change. In some cases mild proliferation of reticuloendothelial cells could be seen. Neither intercellular oedema nor leucocytic infiltrations could be observed.

The kidneys revealed slight nophrotic changes in most of cases. The heart showed variable degrees of myocardiosis; in some cases intermyocardial congestion and haemorrhages could be observed. Examination of the intestine revealed mild catarrhal enteritis associated with necrotic changes in the tips of their villi. No changes were observed in the spleen. In the brain meningeal vascular congestion was observed.

\section{DISCUSSION}

In our findings, the lung revealed different pictures of inflammatory processes. The latter varied not only in severity but also in extent and nature from animal to animal and oven from one area to another in the same lung. The principal features observed were mixed exudative and proliferative reactions associated with necrotic areas. The latter appeared partly infarctive in origin and partly true tissue destruction. The exudative process was represented by serofibrinous and cellular bronchopneumonia with atelectasis and emphysema. The proliferative reaction was seen in the air passages, alveoli and interstitial tissue. Moreover, suppuration and abscessation were common in the lung tissue.

It is known that many infectious agents are associated with pneumonia in cattle; these include Pasteurella haemorrhagica and multocida (ALLEY, 1975; GILMOURI, 1978; BREYSON et al. 1979; CHAUDRASEKARAN and CHUINK, 1981), BEDSONIA and CHLAMYDIA (PHILLIP, 1968), PI-3 virus (FRANK and MARSHALL, 1973), adenoviruses (MOHANTY et al. 1973), respiratory syncytial virus (JACOBS and EDINGTON, 1975), rhinovirrses (MOHANTY et al. 1969), and reovirus (LAMONT et al. 1968; PHILLIP, 1970). In the present study, the affected animals in this outbreak were proved to be serologically positive for PI-3, IBR and BVD viruses (EL-SEBAIE et al. 1983). Moreover, Pasteurella was isolated from nasal swabs and morbid materials. Hepatization, accumulation of serofibrinous exudate, catarrhal bronchitis and bronchiolitis as well as serofibrinous pleurisy observed in the respiratory tract are all a characterstic lesions of Pasteurellosis. However, a combination of previous viral infection and stressora may have played a role. Lesions related to viral infection in the present cases may be overshadowed by the severity of changes induced by bacterial invasions and the primary role of Pasteurella can not be emphyasized. Mixed infections of PI-3, IBR and BVD viruses are not uncommon in young cattle (WHITE and FISHMAN, 1972). Interstitial proliferative inflammation of the lung tissue observed in our materials resembled, most probably, an old bacterial or viral infections occurred earlier.

The necrobiotic changes seen in the lymph nodes draining the respiratory tract could be attributed to either the direct effect of the aetiological agents or indirectly due to the bacterial toxins. The degenerative changes seen in the parenchymatous organs could be considered as secondery lesions.

Assiut Vet.Med.J. Vol. 14, No. 27, 1985. 


\section{A.H. BAYOUMI, et al.}

\section{REFERENCES}

Al-Darraji, A.M.; Cutlip, R.C., Lehmkuhl, D.; Graham, D.; Kluge, J.P. and Frank, G.H. (1982): Experimental infection of lambs with bovine synctial virus and pasteurella haemolytica.

Clinical and microbiological studies. Am. J. Vet. Res., 42, 236-240.

Alley, M.R. (1975): The bacterial flora of respiratory tract of normal and pneumonic sheep. NZ. Vet. J., 23, 113-118.

Betts, A.O.; Jennings, A.R.; Omar, A.R.; Page, Z.E.; Spence, J.B. and Walker, R.G. (1964): Pneumonia in calves caused by PI-3 virus. Vet. Rec., 76, 382-391.

Breyson, D.G.; McFerran, J.B.; Ball, H.J.; Neil, S.O. (1979): Observation on outbreak of respiratory disease in calves associated with $\mathrm{PI}-3$ virus and respiratory syncytial virus infection. Vet. Rec., 104, 45-49.

Chandrasekaran, P.C. and Chuink, Y.P. (1981): Biochemical and serological studies of pasteurella multocida isolated from cattle and buffalo in Malaysia. Brit. Vet. J., 137, 361-367.

Cole, A.M. (1971): Experimental adenovirus pneumonia in calves. Aust. Vet. J., 47, 306-309.

Collier, J.R.; Chow, T.L.; Benjamin, M.M. and Deem, A.W. (1960): The combind effect of infectious bovine rhinotracheitis virus and pasteurella haemolytica on cattle. Am. J. Vet. Res., 21, 195-198.

El-Sebaie, A.; Ibrahim, A.H.; Ibrahim, A.A.; Hofmann, W. and Amer, A.A. (1983): Investigation on an outbreak of enzootic bronchopneumonia in fattening buffalo-calves in Assiut, A.R.E. 1- Clinical, microbiological and haematological studies. Assiut Vet. Med. J., under press.

Frank, G.H. and Marshall, R.G. (1973): PI-3 virus infection of cattle. J. Am. Vet. Med. Ass., 163, $858-860$.

Gilmouri, N.J.L. (1978): Pasteurellosis in sheep. Vet. Rec., 102, 100-102.

Jacobs, J.W. and Edington, N. (1975): Respiratory syncytial virus inffection in calves. Res. Vet. Sci., 18, 299-314.

Jarrett, W.F.H. (1956): The pathology of some types of pneumonia and associated pulmonary diseases of the calf. Brit. Vet. J., 112, 431-442.

Lamont, P.H.; Darbyshire, J.H.; Dawson, P.S.; Omar, A.R. and Jennings, A.R. (1968): Pathogenesis and pathology of infection in calves with strains of reovirus type 1,2. J. Comp. Path., 78, 23-33.

Lehmkuhl, H.D. and Gough, P.M. (1977): Investigation of causative agents of bovine respiratory tract disease in beef cow-calf herd with an early weaning program. Am. J. Vet. Res., 38, 1717-1720.

Mohanty, S.B.; Lillie, M.G.; Albert, T.F. and Sass, B. (1969): Experimental exposure of calves to a bovine rhinovirus. Am. J. Vet. Res., 30, 316-911.

Mohanty, S.B. et al. (1969): Cited by lehmkuhl, H.D. and Gough, P.M. (1977).

Omar, A.R.; Jennings, A.R. and Betts, A.O. (1966): The experimental disease produced in calves by the J. 121 strain of PI-3 virus type 3. Res. Vet. Sci., 7, 379-384.

Moustafa Shams, E.M.; Malik, G.; El-Kalash, S.S. (1975): Giant cell pneumonia in calves. J. Egypt Vet. Med. Ass., 35, 81-94.

Phillip, J.I.H. (1968): Pneumonia in calves. Vet. Rec., 82, (14), 220-226.

Phillip, J.I.H. (1970): Virus pneumonia in calves. Vet. Rec., 86, 280-284.

Pirie, H.M.; Pringle, C.R.; Allan, E.M. and Kennedy, G.J. (1981): Acute fatal pneumonia in calves due to respiratory syncytica virus. Vet. Rec., 104, 411-416.

White, D.J. and Fishman, B. (1972): Cited by lehmkuhl, H.D. and Gough, P.M. (1977).

Assiut Vet.Med.J. Vol. 14, No. 27, 1985. 


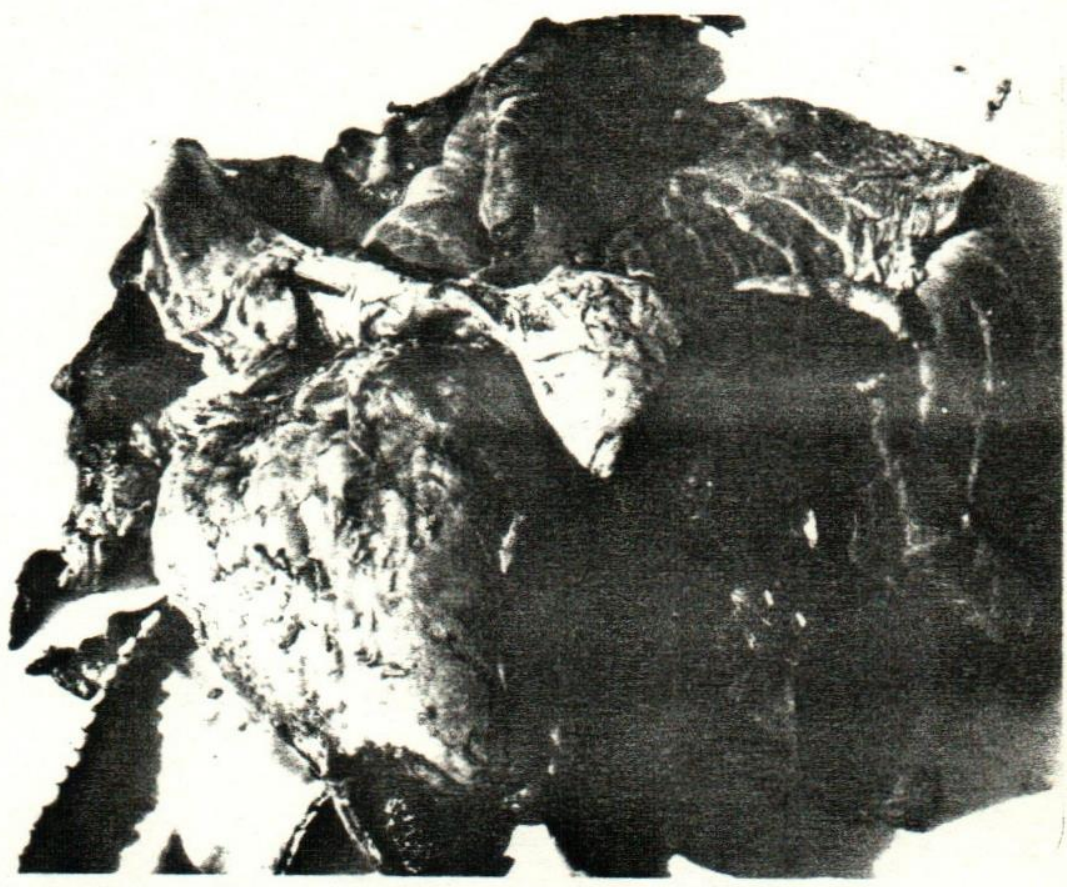

Fig. (1): Showing pneumonic consolidations and fibrinous pericarditis

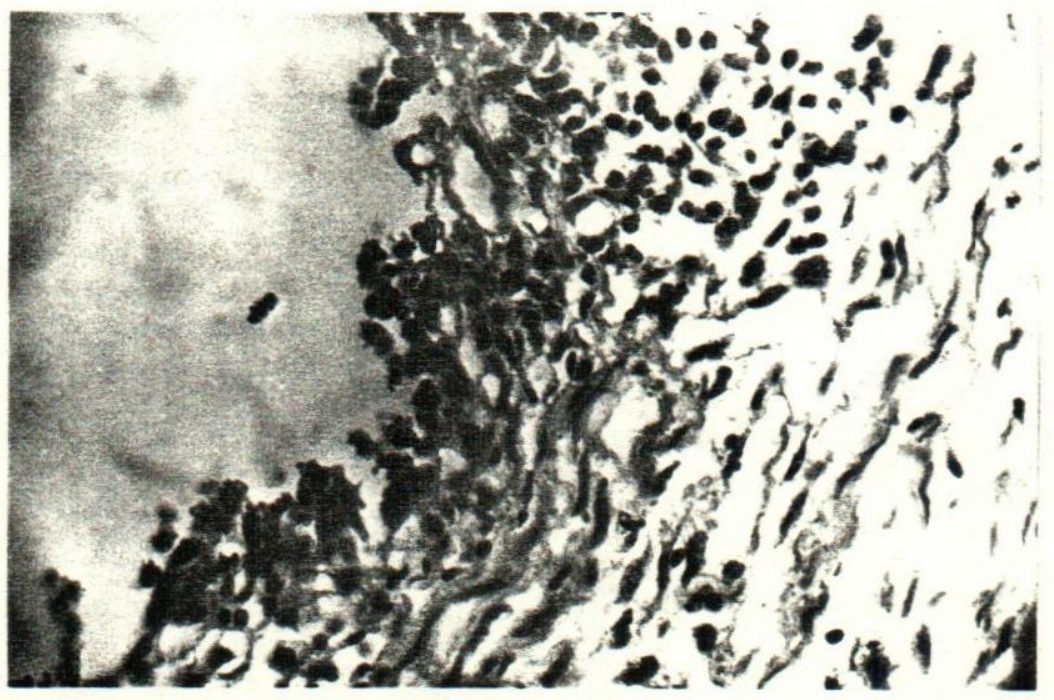

Fig. (2): Bronchiole showing proliferation of its epithelial lining. H.\&E. $\times 25 \times 12.5$ 


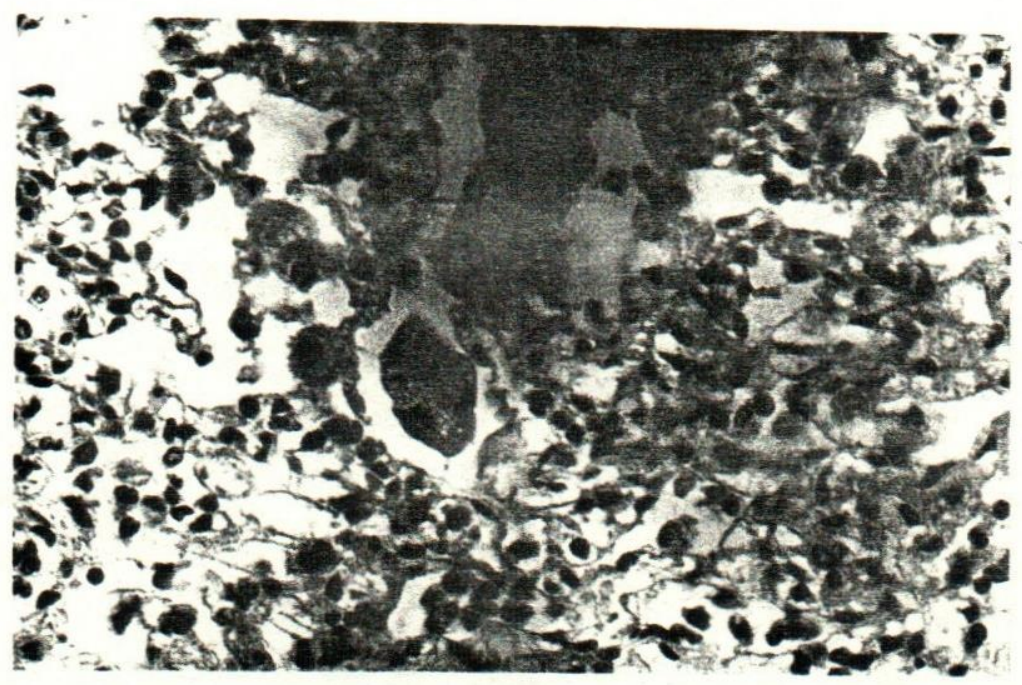

Fig. (3): Lung showing giant cells in the alveolar lumens. H.\&E. $X 40 \times 12.5$

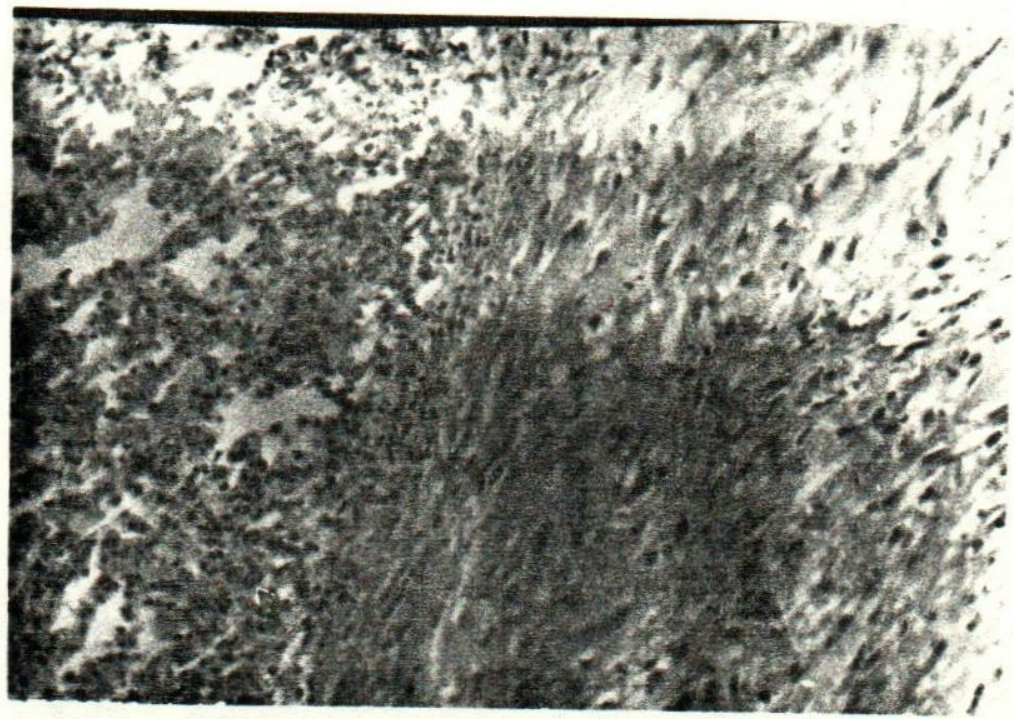

Fig. (4): Lung showing proliferative reaction in the interstitial tissue. H.\&E. $\times 16 \times 12.5$ 
